University of Nebraska - Lincoln

DigitalCommons@University of Nebraska - Lincoln

Faculty Papers and Publications in Animal

Science

Animal Science Department

4-2009

\title{
Nutrient and fiber type relationships in Barrosã muscles
}

P. Costa

Instituto Nacional de Engenharia, Tecnologia e Inovação, Lisboa, Portugal, paulocosta@fmv.utl.pt

L. C. Roseiro

Instituto Nacional de Engenharia, Tecnologia e Inovação, Lisboa, Portugal

V. Alves

Universidade de Trás-os-Montes e Alto Douro, Vila Real, Portugal

Chris R. Calkins

University of Nebraska-Lincoln, ccalkins1@unl.edu

R. J. B. Bessa

Pólo Universitário do Alto da Ajuda, Lisboa, Portugal

See next page for additional authors

Follow this and additional works at: https://digitalcommons.unl.edu/animalscifacpub

Part of the Animal Sciences Commons

Costa, P.; Roseiro, L. C.; Alves, V.; Calkins, Chris R.; Bessa, R. J. B.; and Santos, C., "Nutrient and fiber type relationships in Barrosã muscles" (2009). Faculty Papers and Publications in Animal Science. 617. https://digitalcommons.unl.edu/animalscifacpub/617

This Article is brought to you for free and open access by the Animal Science Department at DigitalCommons@University of Nebraska - Lincoln. It has been accepted for inclusion in Faculty Papers and Publications in Animal Science by an authorized administrator of DigitalCommons@University of Nebraska - Lincoln. 
Authors

P. Costa, L. C. Roseiro, V. Alves, Chris R. Calkins, R. J. B. Bessa, and C. Santos

This article is available at DigitalCommons@University of Nebraska - Lincoln: https://digitalcommons.unl.edu/ animalscifacpub/617 


\title{
Nutrient and fiber type relationships in Barrosã muscles
}

\author{
P. Costa, ${ }^{1,5}$ L. C. Roseiro, ${ }^{1}$ V. Alves, ${ }^{2}$ C. R. Calkins, ${ }^{3}$ R. J. B. Bessa, ${ }^{4,5}$ and C. Santos ${ }^{1}$ \\ ${ }^{1}$ Instituto Nacional de Engenharia, Tecnologia e Inovação, DTIA, Estrada do Paço do Lumiar, 1649-038 Lisboa, Portugal \\ ${ }^{2}$ Universidade de Trás-os-Montes e Alto Douro, Quinta dos Prados-Apartado 202, 5001 Vila Real, Portugal \\ ${ }^{3}$ University of Nebraska-Lincoln, Department of Animal Science, Lincoln, Nebraska, USA \\ ${ }^{4}$ Unidade de Produção Animal L-INIA, INIA, Fonte Boa, 2005-048 Vale de Santarém, Portugal \\ ${ }^{5}$ CIISA, Faculdade de Medicina Veterinária, Avenida da Universidade Técnica, \\ Pólo Universitário do Alto da Ajuda, 1300-477 Lisboa, Portugal \\ Corresponding author - P. Costa, Instituto Nacional de Engenharia, Tecnologia e Inovação, \\ DTIA, Estrada do Paço do Lumiar, 1649-038 Lisboa, Portugal; \\ tel 351 217127107, fax 351 217127162, email paulocosta@fmv.utl.pt
}

\begin{abstract}
Fiber type and nutrient compositions from Biceps femoris (Bf), Longissimus dorsi (Ld) and Supraspinatus (Ss) muscles of 10 Barrosã calves were determined and the respective relationships investigated by principal component analysis (PCA). The Ss muscle had higher proportion of type IIA fibers than Bf $(P<0.001)$ and Ld $(P<0.01)$, higher percentage of oxidative fibers than $\mathrm{Ld}$ muscle $(P<0.01)$ and lower proportion of IIB fibers than Bf $(P<0.001)$ and Ld $(P<0.01)$. The latter muscle had higher intramuscular total lipids (ITL) $(P<0.01)$, neutral lipids (NL) $(P<0.01)$, C18:2c9t11-CLA $(P<0.001)$, saturated fatty acids (SFA) $(P<0.001)$, trans fatty acids (TFA) $(P<0.001)$ and monounsaturated fatty acids (MUFA) $(P<0.01)$ contents than its counterparts. In contrast, Bf and Ss muscles had higher proportions of polyunsaturated fatty acids (PUFA) $(P<0.001), n-6$ PUFA $(P<0.001), n-3$ PUFA $(P<0.01)$, polyunsaturated/saturated fatty acids ratio $(\mathrm{P} / \mathrm{S})(P<0.001)$ and hypocholesterolaemic/hypercholesterolaemic fatty acid ratio $(\mathrm{h} / \mathrm{H})(P<0.001)$ than $\mathrm{Ld}$ muscle. The higher iron $(P<0.001)$ and phospholipids $(\mathrm{PL})(P<0.05)$ contents were found in Ss muscle. Cholesterol amount was unaffected by anatomical location and ranged from 0.50 to $0.54 \mathrm{mg} / \mathrm{g}$. Barrosã muscles were not well distinguishable by PCA since, based on fiber and nutritional compositions, they did not clearly present different patterns. Barrosã-PDO veal is a low fat meat providing 367-558 mg of $n-6$ PUFA and 151-172 mg of $n-3$ PUFA of which $67-78 \mathrm{mg}$ are EPA + DHA (based on $150 \mathrm{~g}$ consumption). The $n-6 / n-3$ ratio was close to the recommended values for human diet and the $\mathrm{p} / \mathrm{s}$ index was below those values.
\end{abstract}

Keywords: Barrosã-PDO veal, fiber type, nutrient composition

\section{Introduction}

Fatty acid (FA) composition influences the nutritive value and sensory characteristics of meat. Since the dietary levels of fat and cholesterol have been related to an increased risk of several chronic diseases, health organizations recommend reductions in total fat as well as particularly saturated fatty acids (SFA), and the increase in ratios of polyunsaturated fatty acids (PUFA) to SFA and n-3/n-6 intake (British Department of Health, 1994). In Western countries, meat has a negative public image and its contribution to the amount of fat, SFA and cholesterol in human diet is well established (Valsta et al., 2005).
However, meat is one of the few dietary sources of long chain ( $\geq$ C20) n-3 FA (Ponnampalam, 2001), but this is frequently less widely recognized. Recent research has focused on the nutritional relevance of trans fatty acids (TFA) and conjugated linoleic acid (CLA) in the human diet. Some CLA isomers are considered beneficial to human health, due to its anticarcinogenic and antiatherogenic properties. In contrast, metabolic studies have shown that some TFA have adverse effects on blood lipid levels (Mulvihill, 2001).

Portuguese population is more diet conscious today, having special concerns about fat and cholesterol associated with meat consumption. For the modern consumer, taste and nu- 
tritional value are important quality attributes of meat (Webb and O'Neill, 2008), with increased expectations in Protected Denomination of Origin (PDO) meat. The consumer's decision to purchase a more expensive PDO food is mainly guided by its high intrinsic quality and healthiness, which in the case of meat is largely related to its fat properties and to the absence of chemical residues. Barrosã-PDO meat is perceived as healthy due to the friendly extensive system used on animal production. Traditional Barrosã veal, produced according to PDO rules (Council Regulation $n^{\circ}$ 2081/92 of $14 / 7$, EEC), has been based on small family herds and involves indoor management, maternal suckling, and complementary diet based on herd products. Being in the past (XIX century) an important exportation issue to the U.K., there are still more than 2000 Barrosã beef producers nowadays, generally owning only 2-5 dams in Minho and 10-15 dams in Barroso, located in the Norwest of Portugal, totalizing about 7500 animals.

Although the importance of Barrosã-PDO veal production on the regional economy is well recognized, being one of the two most important commercial Portuguese veal-PDO (266 carcass tons in 2003; Instituto do Desenvolvimento Rural e Hidráulica, 2003), no published information is available concerning the effect of muscle type on Barrosã-PDO meat composition. Therefore, the aim of this study was to report the nutrient content and fiber profile in Biceps femoris (Bf), Longissimus dorsi (Ld) and Supraspinatus (Ss) muscles and to identify possible interrelationships among nutrients and fiber characteristics in Barrosã PDO-meat.

\section{Materials and methods}

\subsection{Animals and meat samples}

Ten purebred Barrosã calves (7.2 \pm 0.9 months of age and $94.4 \pm 14.1 \mathrm{~kg}$ of carcass weight), raised on a traditional production pasture-based system according to PDO specifications, were used in this study. Dams were maintained on pasture during most of the year and the calves were housed suckling mother's milk until weaning (6-7 months of age). Supplementation with cereal grains and forages (hay, straw, ryegrass and maize) obtained on the farms were provided to calves and dams, during periods of feed scarcity. The calves were slaughtered and dressed in an officially approved slaughterhouse. During the first hour post-mortem, samples were taken from the middle superficial layer of the Longissimus dorsi (L4-L6), and from the distal region of Biceps femoris and Supraspinatus muscles for determination of histological properties. These samples were immediately frozen by immersion into isopentane, cooled by liquid nitrogen, and kept at $-80^{\circ} \mathrm{C}$ until further analysis. For lipid, cholesterol and haem iron evaluations, samples with about $200 \mathrm{~g}$ were excised from Ld (L4-L6) and from the distal region of Bf and Ss muscles 1 day after slaughter and stored under vacuum at $-20^{\circ} \mathrm{C}$, until analysis. Before chemical analyses, the samples were trimmed of visible adipose and connective tissues and minced. Investigated muscles were chosen due to their divergent growth patterns and functionalities in vivo and because they represent meat cuts of different expected eating quality and economical value (round, loin and chuck).

\subsection{Histological traits}

For determination of histological properties, serial transverse muscle sections $\left(10 \mu \mathrm{m}\right.$ thick) were cut in a cryostat at $-24^{\circ} \mathrm{C}$ and stained for myosin adenosine triphosphatase (ATPase) at $\mathrm{pH} 4.45$ and for succinic dehydrogenase (SDH). Fibers identified according to ATPase were classified as type I, type IIA and type IIB, according to Brooke and Kaiser (1970). Type IIC were also identified but did not exceed $5 \%$ of the total fiber population in any section and were not included in the results. The succinic dehydrogenase (SDH) protocol described by Sheehan and Hrapchak (1987) was used to define fiber metabolic types as oxidative or glycolytic. The percentage of each fiber type and its mean cross-sectional area (CSA) was measured in two randomly selected areas on serial sections with an image analysis software program (Vector Works, 2003). On average, 200 fibers were analyzed on each serial section.

\subsection{Fatty acid analysis}

Intramuscular total lipids (ITL) from duplicate $20 \mathrm{~g}$ muscle samples, trimmed of visible adipose and connective tissues were extracted as described by Folch et al. (1957). Lipid extracts were esterified with $\mathrm{KOH}(2 \mathrm{~N})$ in methanol (ISO 5509, 2000) and resulting fatty acid (FA) methyl esters were analyzed by gas-liquid chromatography, using a HRGC 5160, Mega series from Carlo Erba instruments, equipped with a flame ionization detector and a $60 \mathrm{~m}$ long DB 23 capillary column. The oven temperature was raised from 70 to $195^{\circ} \mathrm{C}(10 \mathrm{~min})$, and then to $220^{\circ} \mathrm{C}(60 \mathrm{~min})$ at a rate of $5^{\circ} \mathrm{C} / \mathrm{min}$ for $\mathrm{FA}$ analysis. Injector and detector temperatures were $220^{\circ} \mathrm{C}$ and $280^{\circ} \mathrm{C}$, respectively.

Identification of FA was based on comparison of retention times of the individual FA with standard mixtures (Supelco and Nuchek GLC reference standard FAME mixture) and confirmed using a GC-MS (Saturn 2200, Varian, Walnut Creek, CA, USA) equipped with a fused silica column (BPX-70 $120 \mathrm{~m}$ $\times 0.25 \mathrm{~mm} \times 0.25 \mu \mathrm{m}$, Scientific Instrument Services, Inc.). The FA were expressed as weight percentage.

\subsection{Cholesterol analysis}

Cholesterol was evaluated according to the procedure described by Costa et al. (2006b), using a HPLC apparatus (Spectra-Physics Model Spectra 100) equipped with variable wavelength UV detector set at $206 \mathrm{~nm}$ and a Spherisorb S5W silica cartridge, $5 \mu \mathrm{m}, 4.0 \times 125 \mathrm{~mm}$ (Waters PSS 845549). The mobile phase was hexane/isopropanol (97:3) at a flow rate of $1.0 \mathrm{~mL} / \mathrm{min}$. The cholesterol content was expressed as $\mathrm{g} \mathrm{kg}^{-1}$ of muscle.

\subsection{Haem iron content}

Haem iron was quantified following the analytical procedure of Lombardi-Boccia et al. (2002). Briefly, samples were analyzed for haem pigment content according to Hornsey (1956) and the haem iron concentration was calculated from the standard curve as follows: haem iron (mg/100 g) = hematin content $(\mathrm{mg} / 100 \mathrm{~g}) \times \mathrm{AW} / \mathrm{MW}$, where $\mathrm{AW}$ is the atomic weight of iron and MW the molecular weight of hematin. 
Table I. Muscle fiber composition in Biceps femoris (Bf), Longissimus dorsi (Ld) and Supra spinatus (Ss) muscles from Barrosã calves $(n=10)$.

\begin{tabular}{|c|c|c|c|c|c|}
\hline \multirow[t]{2}{*}{ Trait } & \multicolumn{3}{|l|}{ Muscle } & \multirow[t]{2}{*}{ SE } & \multirow[t]{2}{*}{ Effect } \\
\hline & $\mathrm{Bf}$ & Ld & Ss & & \\
\hline \multicolumn{6}{|c|}{ Fiber type distribution (\%) } \\
\hline I & 22.35 & 22.08 & 22.79 & 1.44 & \\
\hline IIA & $17.77^{c}$ & $22.27^{b}$ & $28.48^{\mathrm{a}}$ & 1.49 & \\
\hline IIB & $59.87^{\mathrm{a}}$ & $54.58^{b}$ & $48.73^{c}$ & 1.90 & \\
\hline Oxidative & $51.96^{\mathrm{ab}}$ & $48.69^{b}$ & $54.13^{\mathrm{a}}$ & 1.31 & \\
\hline \multicolumn{6}{|c|}{ Fiber cross-sectional area-CSA $\left(\mu m^{2}\right)$} \\
\hline 1 & $997.00^{\mathrm{b}}$ & $1281.28^{\mathrm{a}}$ & $1400.63^{\mathrm{a}}$ & 106.29 & \\
\hline IIA & 1592.20 & $|845.8|$ & 1607.93 & 120.14 & \\
\hline IIB & $2227.40^{b}$ & $2521.21^{\mathrm{a}}$ & $1789.74^{c}$ & 125.28 & \\
\hline Glycolytic & $2679.03^{\mathrm{a}}$ & $2697.35^{\mathrm{a}}$ & $1912.86^{\mathrm{b}}$ & 153.82 & \\
\hline Oxidative & 1347.17 & $|450.6|$ & 1465.99 & 95.02 & \\
\hline \multicolumn{6}{|c|}{ Relative area of the muscle-RA (\%) } \\
\hline I & $12.03^{\mathrm{b}}$ & $13.69^{\mathrm{b}}$ & $19.40^{\mathrm{a}}$ & 1.39 & \\
\hline IIA & $16.04^{c}$ & $20.50^{b}$ & $27.68^{\mathrm{a}}$ & 1.95 & \\
\hline IIB & $71.93^{\mathrm{a}}$ & $65.92^{b}$ & $\left.52.9\right|^{\mathrm{c}}$ & 2.41 & \\
\hline Oxidative & $35.53^{\mathrm{b}}$ & $33.69^{b}$ & $47.66^{\mathrm{a}}$ & 1.82 & \\
\hline
\end{tabular}

ns $=$ not statistically significant; $* P<0.05 ; * * P<0.01$; *** $P<0.001$.

Means in the same row with different superscripts are different $(P<0.05)$. $\mathrm{SE}=$ standard error.

\subsection{Statistical analysis}

The data were analyzed using the MIXED procedure of SAS 9.1.3 (2004), considering the animal within the group as subject and the muscle as repeated measures. Analysis of means was performed by the LSD test for 95\% probability. Pearson correlation coefficients were generated between the variables studied. A principal component analysis (PCA) of meat composition was carried out using STATISTICA software (StatSoft Inc., 2004), with the variables for PCA being standardized to a mean of zero and variance of one. The PCA has been used before with sensory and nutritional data to describe meat quality (Galbraith et al., 2006). Most applications of chemical data analysis are by nature multivariate and the most suitable method for such cases is PCA (Sharaf et al., 1986). PCA is based on the correlation among variables mapping samples through scores and variables by the loadings in a new space defined by the principal components (PC). The PC are simple linear combination of original variables. Score plots allow sample identification, checking if they are similar or dissimilar, typical or outlier. The most important variables are identified from the loadings. An important point in such evaluation is that maximum variability in the data can be explained in a reduced variable set. The first principal component, PC1, is defined in the direction of maximum variance in the data set, and the subsequent components are orthogonal (uncorrelated) to one another and maximize the remaining variance.

\section{Results}

\subsection{Fiber type characteristics}

Fiber type distribution, their cross-sectional area (CSA) and the relative area of the muscle occupied by each fiber type (RA) in Bf, Ld and Ss muscles are summarized in Table 1. The Ss muscle had higher proportion of type IIA fibers than Bf
Table 2. Intramuscular total lipids (ITL, $\mathrm{g} \mathrm{kg}^{-1}$ ), neutral lipids (NL, $\mathrm{g} \mathrm{kg}^{-1}$ ), phospholipids ( $\left.\mathrm{PL}, \mathrm{g} \mathrm{kg}^{-1}\right)$, cholesterol $\left(\mathrm{g} \mathrm{kg}^{-1}\right.$ ) and haemic iron ( $\left.\mathrm{mg} \mathrm{kg}^{-1}\right)$ and main fatty acid contents (w/w \%) in Biceps femoris (Bf), Longissimus dorsi (Ld) and Supra spinatus (Ss) muscles from Barrosã calves $(n=10)$.

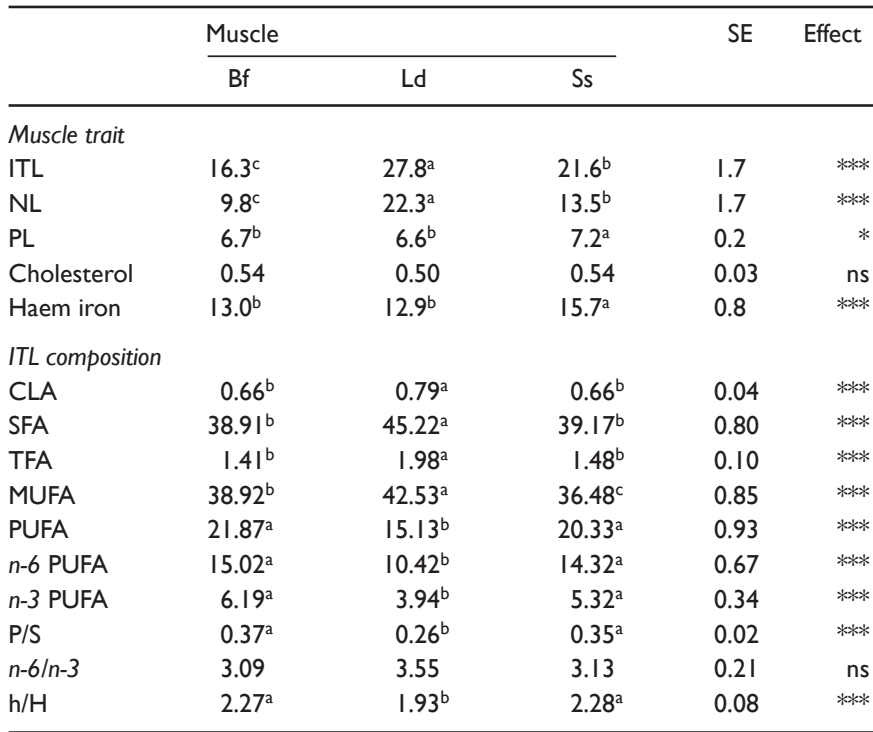

CLA = C 18:2c9t I I;SFA = saturated fatty acids;TFA = trans fatty acids;

MUFA $=$ monounsaturated fatty acids; PUFA $=$ polyunsaturated fatty acids. $n-3$ PUFA $=\mathrm{C} 18: 3 n-3+\mathrm{C} 20: 3 n-3+\mathrm{C} 20: 5 n-3+\mathrm{C} 22: 5 n-3+\mathrm{C} 22: 6 n-3$.

$n-6$ PUFA $=C 18: 2 n-6+C 18: 3 n-6+C 20: 3 n-6+C 20: 3 n-6+C 20: 4 n-6$ $+C 22: 2 n-6+C 22: 4 n-6$

$\mathrm{P} / \mathrm{S}=(\mathrm{Cl} 8: 2 n-6+\mathrm{Cl} 8: 3 n-3) /(\mathrm{Cl} 4: 0+\mathrm{Cl} 6: 0+\mathrm{Cl} 8: 0)$.

$\mathrm{h} / \mathrm{H}=$ hypocholesterolaemic/hypercholesterolaemic ratio $=(\mathrm{Cl} 8: 1 \mathrm{c} 9$

$+\mathrm{Cl} 8: 2 n-6+\mathrm{Cl} 8: 3 n-6+\mathrm{Cl} 18: 3 n-3+\mathrm{C} 20: 2 n-6+\mathrm{C} 20: 3 n-6+\mathrm{C} 20: 3 n-3$

$+C 20: 4 n-6+C 20: 5 n-3+C 22: 2 n-6+C 22: 4 n-6+C 22: 5 n-3$

$+\mathrm{C} 22: 6 n-3) /(\mathrm{Cl} 2: 0+\mathrm{Cl} 4: 0+\mathrm{Cl} 6: 0)]$.

ns $=$ not statistically significant, $* P<0.05 ; * * P<0.01 ; * * * P<0.001$

Means in the same row with different superscripts are different $(P<0.05)$.

$\mathrm{SE}=$ standard error

$(P<0.001)$ and Ld $(P<0.01)$, higher proportion of oxidative fibers than Ld muscle $(P<0.01)$ and lower proportion of IIB fibers than Bf $(P<0.001)$ and $\mathrm{Ld}(P<0.01)$. The CSA of type I fibers was higher $(P<0.01)$ in $\mathrm{Ld}$ and $\mathrm{Ss}$ muscles than in Bf, while the CSA of type IIB fibers was higher in the Ld muscle than in $\mathrm{Bf}(P<0.05)$ and Ss muscles $(P<0.001)$. The latter had glycolytic fibers with lower CSA $(P<0.001)$ and higher RA occupied by type I $(P<0.01-0.001)$, IIA $(P<0.001)$ and oxidative fibers $(P<0.001)$ than Bf and Ld muscles.

\subsection{Nutritional composition}

Intramuscular total lipids (ITL), neutral lipids (NL), phospholipids (PL), cholesterol and haemic iron contents and FA composition and nutritional relevant $\mathrm{FA}$ ratios in $\mathrm{Bf}, \mathrm{Ld}$ and $\mathrm{Ss}$ muscles from Barrosã calves are presented in Table 2.

The Ld muscle had higher ITL $(P<0.01)$ and NL $(P<0.01)$ contents than $\mathrm{Bf}$ and $\mathrm{Ss}$ muscles. The latter had higher ITL $(P<0.01)$ and NL $(P<0.05)$ amounts than Bf muscle and higher haemic iron $(P<0.001)$ and PL $(P<0.05)$ contents than $\mathrm{Bf}$ and Ld muscles. Cholesterol levels were unaffected by anatomical location and ranged from 0.50 to $0.54 \mathrm{~g} \mathrm{~kg}^{-1}$.

The Ld muscle had higher levels of C18:2c9t11-CLA $(P<0.001)$, SFA $(P<0.001)$, TFA $(P<0.001)$ and MUFA $(P<0.01)$ than its counterparts (Table 2). Conversely, Bf and 


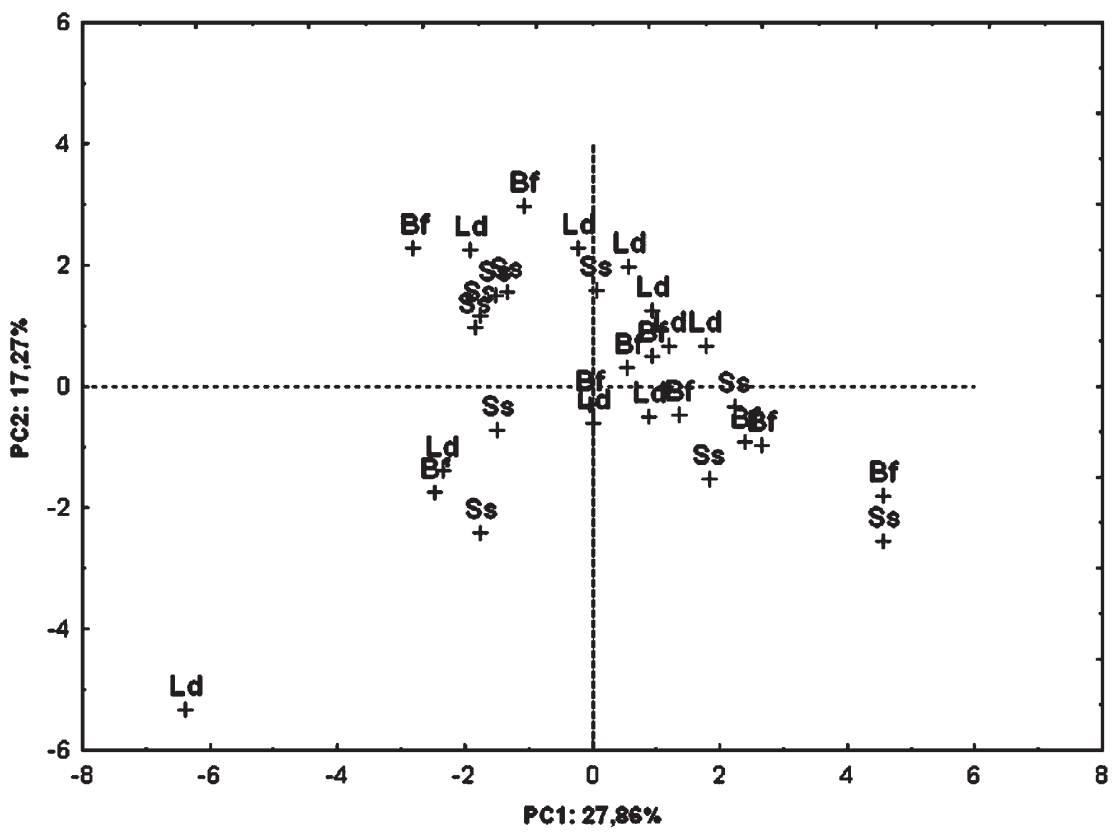

Figure 1. Projection of the data of the Biceps femoris (Bf), Longissimus dorsi (Ld) and Supra spinatus (Ss) muscles defined by the two first principal components.

Ss muscles had higher proportions of PUFA $(P<0.001), n-6$ PUFA $(P<0.001), n$-3 PUFA $(P<0.01)$, polyunsaturated/saturated ratio $(\mathrm{P} / \mathrm{S})(P<0.001)$ and hypocholesterolaemic/hyper-

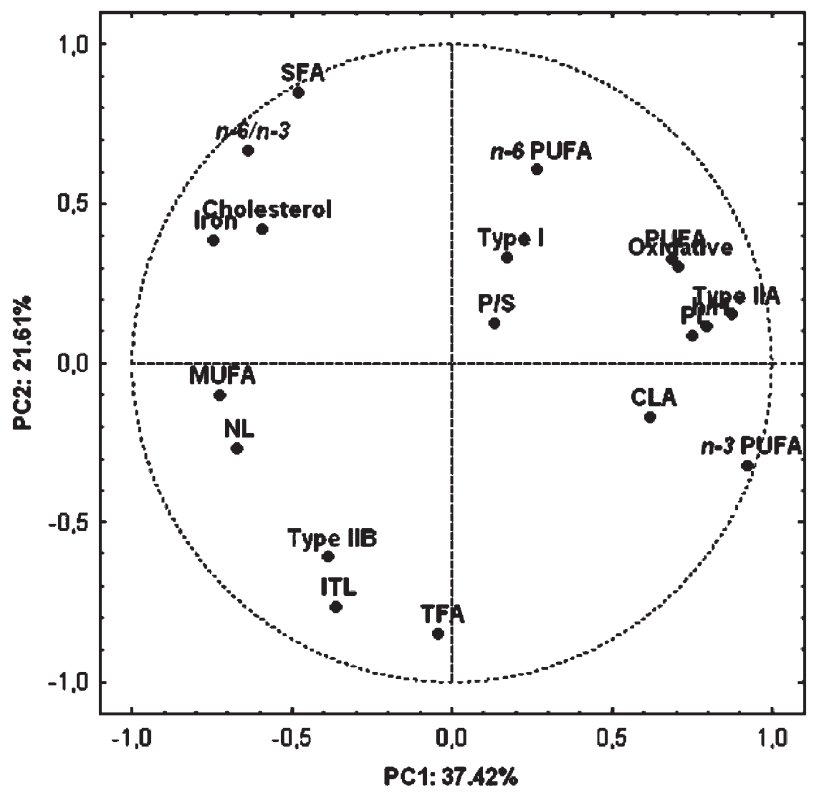

Figure 2. Projection of the variables in the plane defined by the two first principal components for Biceps femoris (Bf) muscle. Abbreviations: ITL $=$ intramuscular total lipids; $\mathrm{NL}=$ neutral lipids; $\mathrm{PL}=$ polar lipids; $\mathrm{SFA}=$ saturated fatty acids; $\mathrm{TFA}=$ trans fatty acids; $\mathrm{MU}$ $\mathrm{FA}=$ monounsaturated fatty acids; $\mathrm{PUFA}=$ polyunsaturated fatty acids; CLA $=$ C18:2c9t11; n-3PUFA $=$ C18:3n-3 + C20:3n-3 + C20:5n-3 + C22:5n$3+\mathrm{C} 22: 6 n-3 ; \quad n-6 \quad$ PUFA $=\mathrm{C} 18: 2 n-6+\mathrm{C} 18: 3 n-6+\mathrm{C} 20: 2 n-6+\mathrm{C} 20: 3 n-$ $6+\mathrm{C} 20: 4 n-6+\mathrm{C} 22: 2 n-6+\mathrm{C} 22: 4 n-6 ; \quad \mathrm{P} / \mathrm{S}=(\mathrm{C} 18: 2 n-6+\mathrm{C} 18: 3 n-3) /(\mathrm{C} 1$ 4:0 + C16:0 + C18:0) $; \quad \mathrm{h} / \mathrm{H}=$ hypocholesterolaemic/hypercholesterolaemic ratio $=[($ sum of C18:1c9, C18:2n-6, C18:3n-6, C18:3n-3, C20:2n-6, C20:3n-6, C20:3n-3, C20:4n-6, C20:5n-3, C22:2n-6, C22:4n-6, C22:5n-3 and C22:6n-3)/(sum of C12:0, C14:0 and C16:0)]. cholesterolaemic ratio $(\mathrm{h} / \mathrm{H})(P<0.001)$ than Ld muscle. Despite those differences, the $n-6 / n-3$ ratio was similar among muscles.

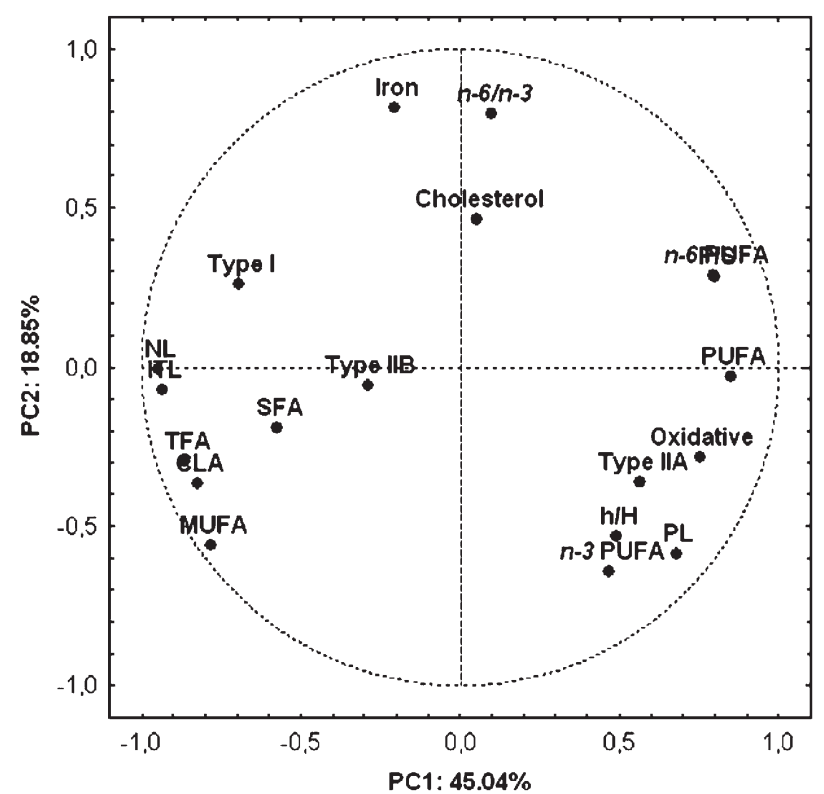

Figure 3. Projection of the variables in the plane defined by the two first principal components for Longissimus dorsi (Ld) muscle. Abbreviations: ITL = intramuscular total lipids; $\mathrm{NL}=$ neutral lipids; $\mathrm{PL}=$ polar lipids SFA = saturated fatty acids; TFA = trans fatty acids; $\mathrm{MU}$ $\mathrm{FA}=$ monounsaturated fatty acids; PUFA = polyunsaturated fatty acids; CLA $=$ C18:2c9t11; $n$-3PUFA $=$ C18:3n-3 + C20:3n-3 + C20:5n-3 + C22:5n$3+\mathrm{C} 22: 6 n-3 ; \quad n-6 \quad$ PUFA $=\mathrm{C} 18: 2 n-6+\mathrm{C} 18: 3 n-6+\mathrm{C} 20: 2 n-6+\mathrm{C} 20: 3 n-$ $6+\mathrm{C} 20: 4 n-6+\mathrm{C} 22: 2 n-6+\mathrm{C} 22: 4 n-6 ; \quad \mathrm{P} / \mathrm{S}=(\mathrm{C} 18: 2 n-6+\mathrm{C} 18: 3 n-3) /(\mathrm{C} 1$ 4:0 + C16:0 + C18:0); h/H = hypocholesterolaemic/hypercholesterolaemic ratio $=[($ sum of C18:1c9, C18:2n-6, C18:3n-6, C18:3n-3, C20:2n-6, $\mathrm{C} 20: 3 n-6, \mathrm{C} 20: 3 n-3, \mathrm{C} 20: 4 n-6, \mathrm{C} 20: 5 n-3, \mathrm{C} 22: 2 n-6, \mathrm{C} 22: 4 n-6, \mathrm{C} 22: 5 n-3$ and C22:6n-3)/(sum of C12:0, C14:0 and C16:0)]. 


\subsection{Principal component analysis and correlations between traits}

The results of the PCA are presented in Figures 1-4 and Table 3. Figure 1 shows the projected data of the Bf, Ld and Ss muscles in the plane defined by the first two PC and does not exhibit separated groups of points. The PC1 in Bf muscle explained $37 \%$ of the total variation (Figure 2 ) and was mainly characterized by PUFA, $n-3$ PUFA, h/H, PL, oxidative and IIA fibers on the right side and haemic iron and MUFA on the left side. The PC2 explained more than $21 \%$ of the variation and was defined by SFA and in the opposite direction by ITL and TFA.

Regarding Ld muscle (Figure 3), PC1 and PC2 explained $45 \%$ and $19 \%$ of the variance, respectively. Two groups of variables were clearly distinguished lying on the PC1, far from the origin. The first group included PUFA, $n-6$ PUFA, P/S and oxidative fibers in the right side of the plot. The other group included ITL, NL, CLA, TFA and MUFA components, lying in the left hand side of the plot. The PC2 was mainly affected by iron and $n-6 / n-3$ and by $n-3$ located in the opposite direction.

The PC1 accounted for $33 \%$ of the total variation of the nutrient and fiber compositions in Ss muscle. This component was mainly influenced by polyunsaturated fatty acids (PUFA, n-6 PUFA and $n-3$ PUFA), CLA and $\mathrm{h} / \mathrm{H}$ on the right side and MUFA and $n-6 / n-3$ on the left side of the plot. The PC2 in Ss muscle explained $24 \%$ of the variance and was influenced by $\mathrm{NL}$ and iron and by a group of components (PL, cholesterol

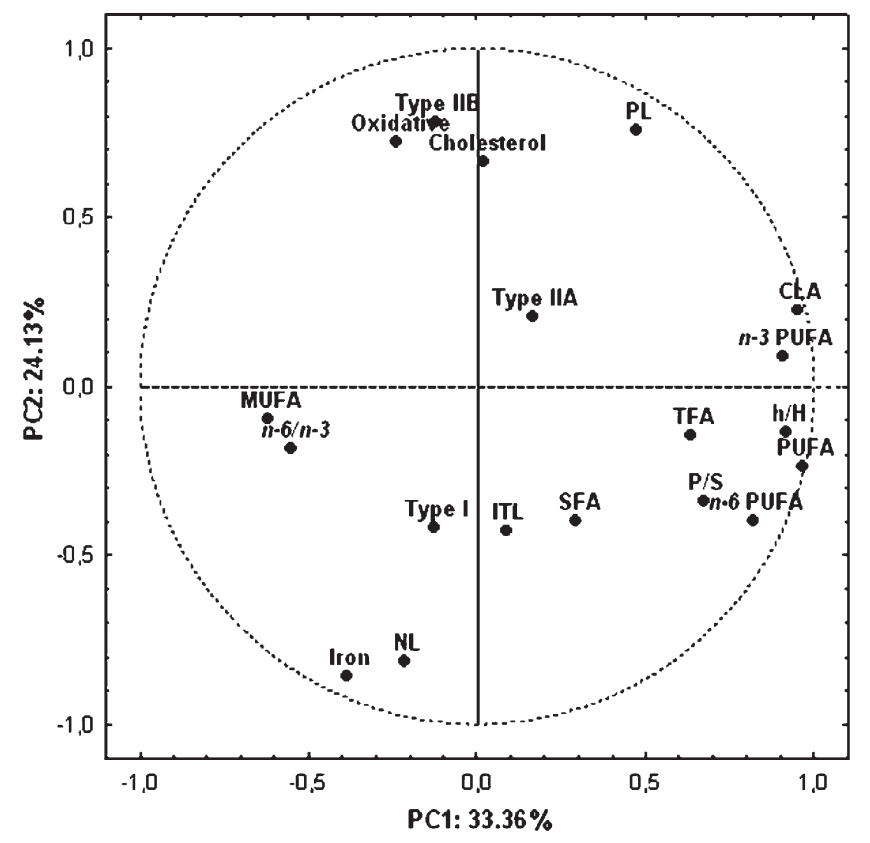

Figure 4. Projection of the variables in the plane defined by the two first principal components for Supraspinatus (Ss) muscle. Abbreviations: $\mathrm{ITL}=$ intramuscular total lipids; $\mathrm{NL}=$ neutral lipids; $\mathrm{PL}=$ polar lipids SFA = saturated fatty acids; TFA = trans fatty acids; MU$\mathrm{FA}=$ monounsaturated fatty acids; PUFA = polyunsaturated fatty acids; CLA $=$ C18:2c9t11 n-3 PUFA $=\mathrm{C} 18: 3 n-3+\mathrm{C} 20: 3 n-3+\mathrm{C} 20: 5 n-3+\mathrm{C} 22: 5 n-$ $3+\mathrm{C} 22: 6 n-3 ; \quad n-6 \quad$ PUFA $=\mathrm{C} 18: 2 n-6+\mathrm{C} 18: 3 n-6+\mathrm{C} 20: 2 n-6+\mathrm{C} 20: 3 n-$ $6+\mathrm{C} 20: 4 n-6+\mathrm{C} 22: 2 n-6+\mathrm{C} 22: 4 n-6 ; \quad \mathrm{P} / \mathrm{S}=(\mathrm{C} 18: 2 n-6+\mathrm{C} 18: 3 n-3) /(\mathrm{C} 1$ 4:0 + C16:0 + C18:0) $\quad \mathrm{h} / \mathrm{H}=$ hypocholesterolaemic/hypercholesterolaemic ratio $=[($ sum of C18:1c9, C18:2n-6, C18:3n-6, C18:3n-3, C20:2n-6, C20:3n-6, C20:3n-3, C20:4n-6, C20:5n-3, C22:2n-6, C22:4n-6, C22:5n-3 and C22:6n-3)/(sum of C12:0, C14:0 and C16:0)]. and type IIB and oxidative fibers) located in the opposite extreme of the plot.

Pearson correlation coefficients between nutrients and fiber profiles in muscles Bf, Ld and Ss are shown in Tables 46 , respectively. Regarding Bf muscle, type I fibers were negatively correlated with NL $(r=-0.63, P<0.05)$. The proportion of type IIA fibers was positively correlated with PL $(r=0.64$, $P<0.05)$, oxidative fibers $(r=0.63, P<0.05), \quad \mathrm{C} 18: 2 c 9 t 11$ CLA $(r=0.65, P<0.05), n-3$ PUFA $(r=0.83, P<0.01)$ and $h /$ $\mathrm{H}(r=0.68, P<0.05)$. Negative correlations were observed between IIA fibers and the proportions of NL $(r=-0.63, P<0.05)$ and MUFA $(r=-0.63, P<0.05)$. The ITL $(r=0.64, P<0.05)$ was positively correlated with type IIB fibers. The proportion of oxidative fibers was significantly correlated with the amounts of NL $(r=-0.70, P<0.05)$ and PL $(r=0.63, P<0.05)$.

Significant correlations were observed between type I fibers in Ld muscle and the levels of ITL $(r=0.69, P<0.05)$, NL $(r=0.69, P<0.05)$ and PL $(r=-0.63, P<0.05)$ and the proportion of IIA fibers $(r=-0.93, P<0.001)$. The percentage of the latter fibers was correlated with PL $(r=0.63, P<0.05)$. The oxidative fibers in Ld muscle were positively correlated with PL $(r=0.70, P<0.05)$ and negatively correlated with the levels of ITL $(r=-0.82, P<0.01)$ and NL $(r=-0.85, P<0.01)$.

Regarding Ss muscle, the PL content was negatively correlated with type I fibers $(r=-0.66, P<0.05)$ and positively correlated with oxidative fibers $(r=0.66, P<0.05)$ and IIB

Table 3. Coefficients of the loadings (eigenvectors) for the first two principal components (PC).

\begin{tabular}{|c|c|c|c|c|c|c|}
\hline \multirow[t]{2}{*}{ Component } & \multicolumn{2}{|c|}{$\mathrm{Bf}(n=10)$} & \multicolumn{2}{|c|}{$\operatorname{Ld}(n=10)$} & \multicolumn{2}{|c|}{ Ss $(n=10)$} \\
\hline & $\mathrm{PCl}(\%)$ & PC2 (\%) & PCI (\%) & PC2 (\%) & $\mathrm{PCl}(\%)$ & PC2 (\%) \\
\hline ITL & -0.36 & -0.77 & -0.93 & -0.07 & 0.09 & -0.43 \\
\hline NL & -0.67 & -0.27 & -0.95 & -0.01 & -0.21 & -0.82 \\
\hline PL & 0.75 & 0.08 & 0.68 & -0.59 & 0.47 & 0.76 \\
\hline Cholesterol & -0.59 & 0.42 & 0.05 & 0.47 & 0.02 & 0.66 \\
\hline Iron & -0.75 & 0.38 & -0.21 & 0.81 & -0.39 & -0.86 \\
\hline Type I & 0.17 & 0.33 & -0.69 & 0.26 & -0.13 & -0.42 \\
\hline Type IIA & 0.88 & 0.15 & 0.58 & -0.36 & 0.16 & 0.20 \\
\hline Tipe IIB & -0.39 & -0.61 & -0.29 & -0.06 & -0.12 & 0.78 \\
\hline Oxidative & 0.71 & 0.30 & 0.75 & -0.28 & -0.24 & 0.72 \\
\hline CLA & 0.62 & -0.17 & -0.83 & -0.37 & 0.95 & 0.22 \\
\hline SFA & -0.48 & 0.85 & -0.57 & -0.19 & 0.29 & -0.40 \\
\hline TFA & -0.04 & -0.85 & -0.86 & -0.30 & 0.64 & -0.15 \\
\hline MUFA & -0.72 & -0.10 & -0.78 & -0.56 & -0.62 & -0.10 \\
\hline PUFA & 0.69 & 0.32 & 0.85 & -0.03 & 0.96 & -0.24 \\
\hline n-6 PUFA & 0.27 & 0.60 & 0.80 & 0.29 & 0.82 & -0.40 \\
\hline n-3 PUFA & 0.92 & -0.32 & 0.47 & -0.64 & 0.91 & 0.09 \\
\hline $\mathrm{P} / \mathrm{S}$ & 0.13 & 0.12 & 0.80 & 0.29 & 0.67 & -0.34 \\
\hline$n-6 / n-3$ & -0.64 & 0.67 & 0.10 & 0.80 & -0.55 & -0.19 \\
\hline$h / H$ & 0.80 & 0.12 & 0.49 & -0.53 & 0.92 & -0.13 \\
\hline
\end{tabular}

$\mathrm{CLA}=\mathrm{Cl}$ 8:2c9t II; SFA = saturated fatty acids; TFA = trans fatty acids;

MUFA $=$ monounsaturated fatty acids; PUFA $=$ polyunsaturated fatty acids $n-3$ PUFA $=\mathrm{C} 18: 3 n-3+\mathrm{C} 20: 3 n-3+\mathrm{C} 20: 5 n-3+\mathrm{C} 22: 5 n-3+\mathrm{C} 22: 6 n-3$

$n-6$ PUFA $=\mathrm{Cl} 8: 2 n-6+\mathrm{Cl} 8: 3 n-6+\mathrm{C} 20: 2 n-6+\mathrm{C} 20: 3 n-6+\mathrm{C} 20: 4 n-6$

$+C 22: 2 n-6+C 22: 4 n-6 ; P / S=(C|8: 2 n-6+C| 8: 3 n-3) /(C \mid 4: 0+C 16: 0$ $+\mathrm{Cl} 8: 0)$.

$\mathrm{P} / \mathrm{S}=(\mathrm{Cl} 8: 2 n-6+\mathrm{Cl} 8: 3 n-3) /(\mathrm{Cl} 4: 0+\mathrm{Cl} 6: 0+\mathrm{Cl} 8: 0)$.

$\mathrm{h} / \mathrm{H}=$ hypocholesterolaemic/hypercholesterolaemic ratio $=(\mathrm{Cl} 8: 1 \mathrm{c} 9$ $+\mathrm{Cl} 8: 2 n-6+\mathrm{Cl} 8: 3 n-6+\mathrm{Cl} 8: 3 n-3+\mathrm{C} 20: 2 n-6+\mathrm{C} 20: 3 n-6+\mathrm{C} 20: 3 n-3$

$+C 20: 4 n-6+C 20: 5 n-3+C 22: 2 n-6+C 22: 4 n-6+C 22: 5 n-3$

$+\mathrm{C} 22: 6 n-3) /(\mathrm{Cl} 2: 0+\mathrm{Cl} 4: 0+\mathrm{Cl} 6: 0)]$

The most significant loadings are highlighted in boldface. 


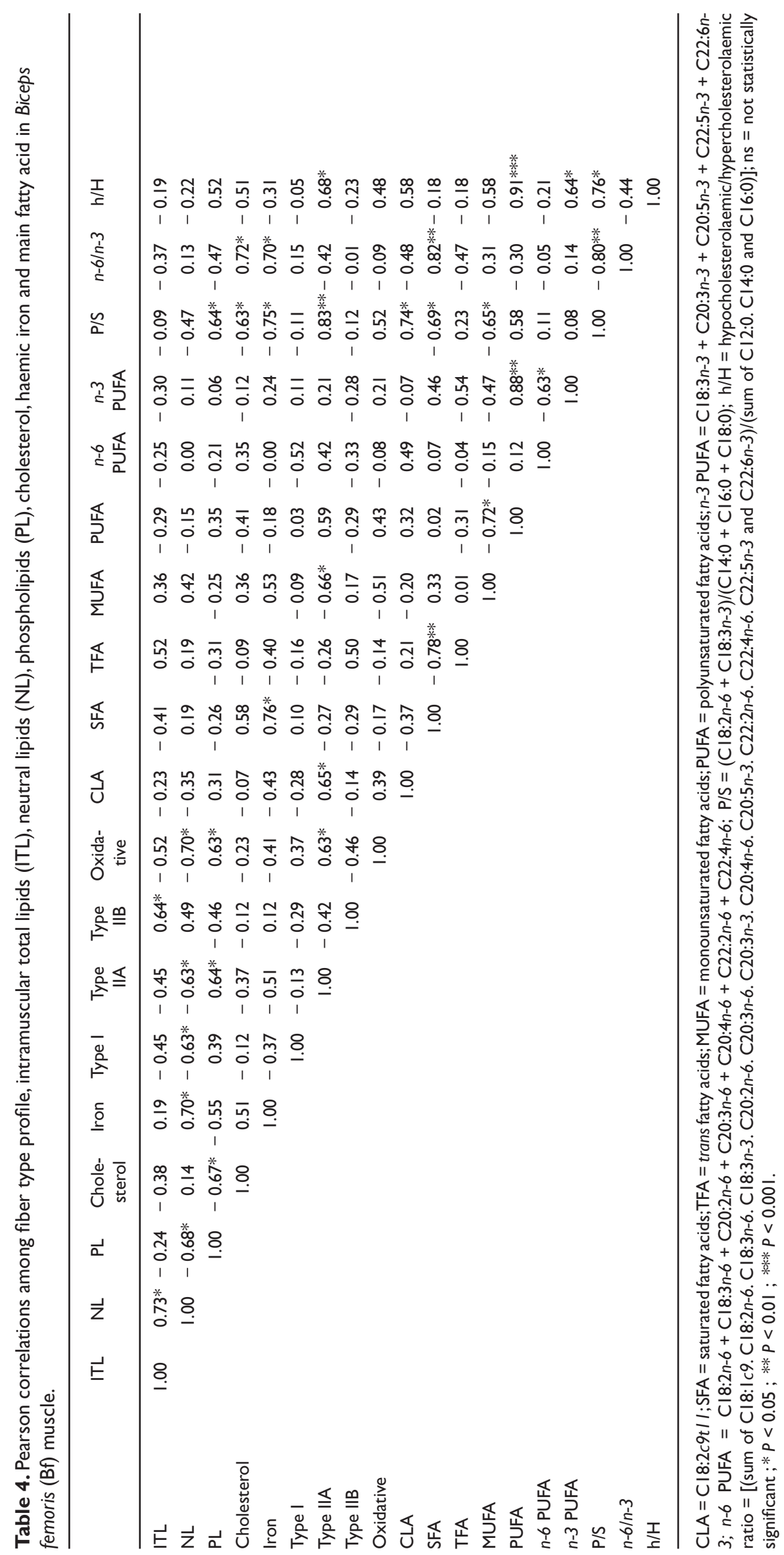




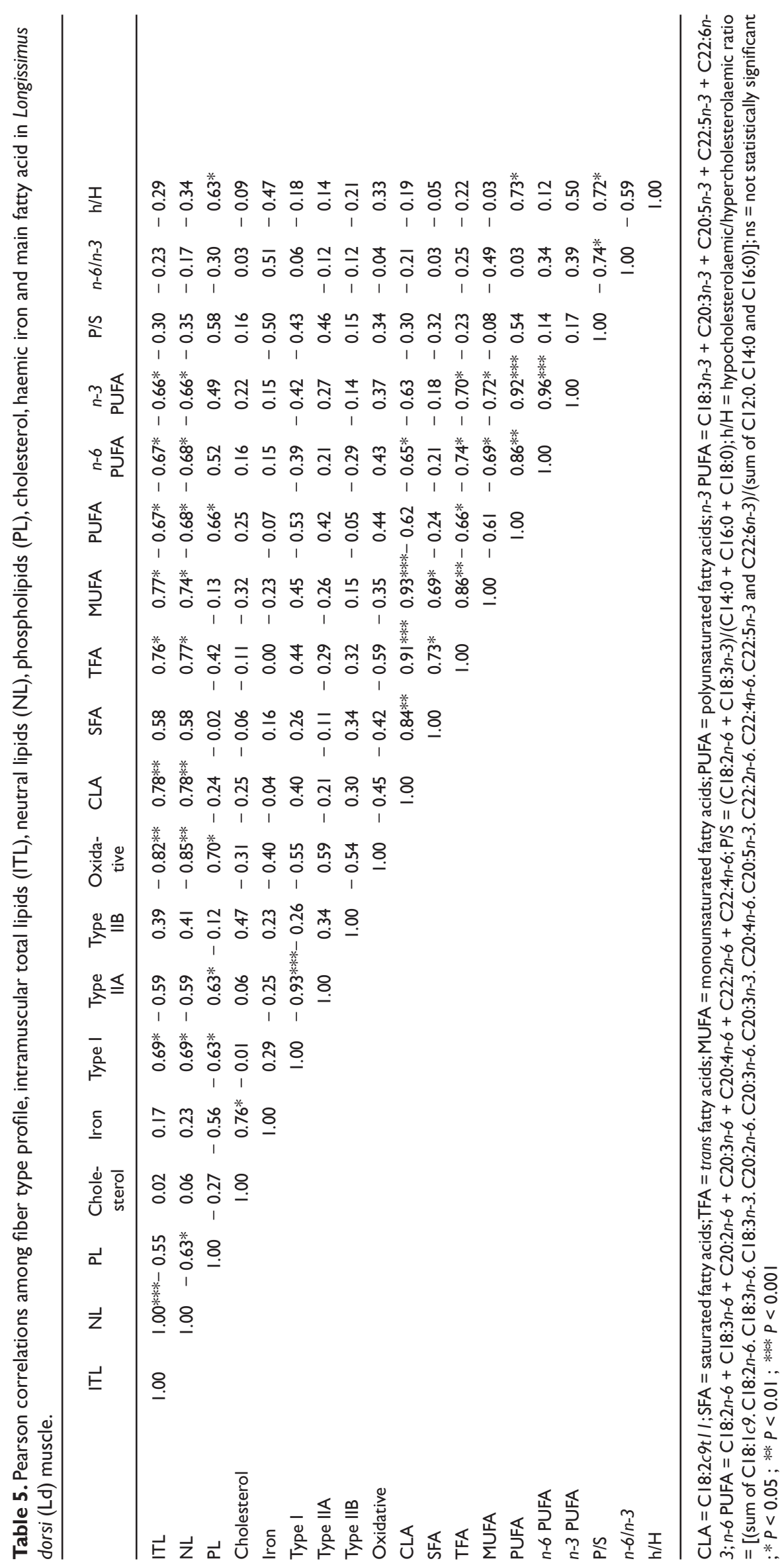




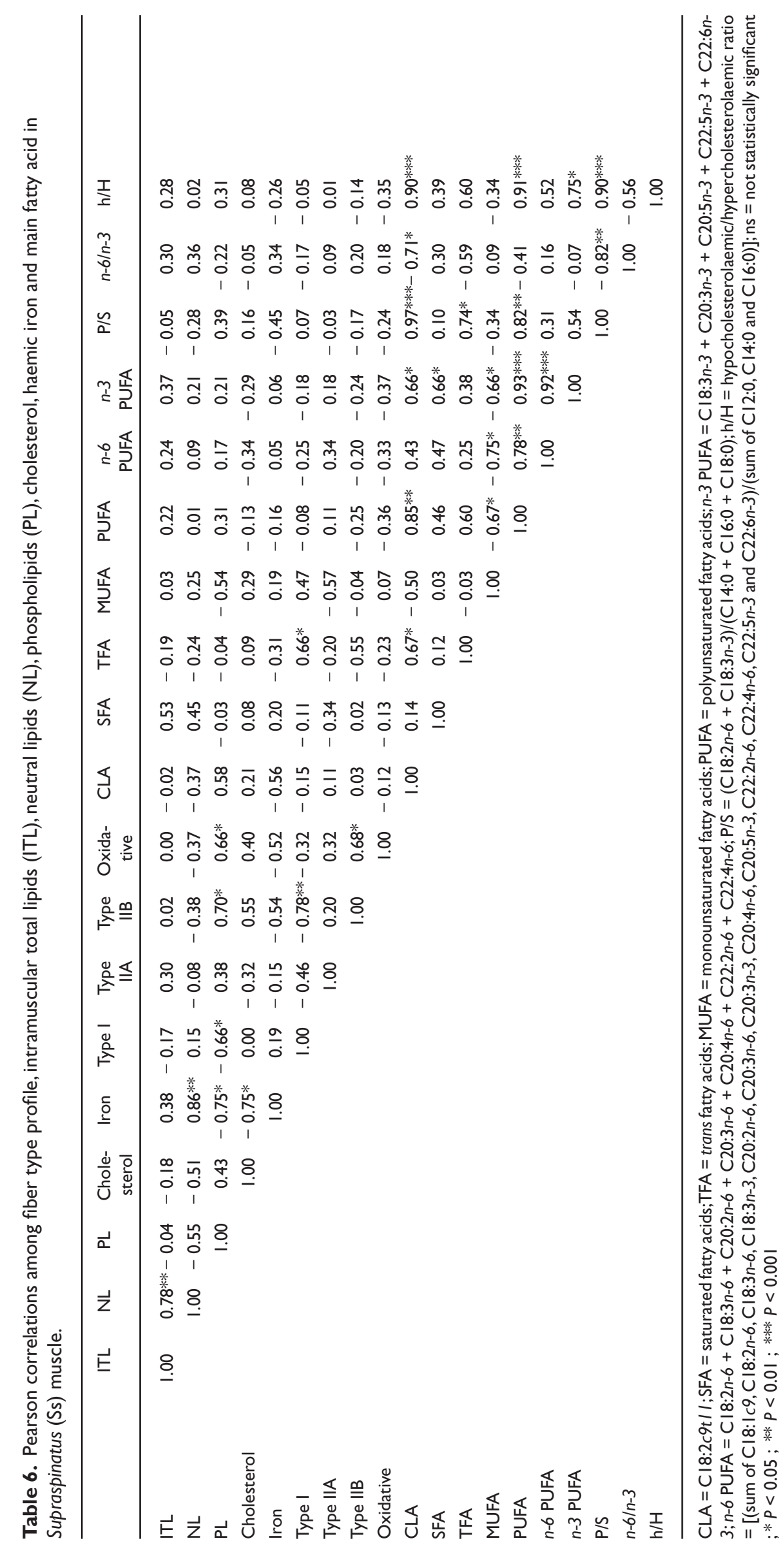


$(r=0.70, P<0.05)$. The latter was positively correlated with oxidative fibers $(r=0.68, P<0.05)$ and negatively correlated with type I fibers $(r=-0.78, P<0.01)$. The proportion of type I fibers was correlated with TFA $(r=0.68, P<0.05)$ in Ss muscle.

\section{Discussion}

\subsection{Nutritional composition and muscle fiber profile}

According to fiber proportions, $\mathrm{Bf}, \mathrm{Ld}$ and Ss can be considered as muscles of intermediate metabolism with the latter presenting a more oxidative prone than $\mathrm{Bf}$, which is more evident when the relative area occupied by each fiber type is considered (Table 1). These results are in good agreement with PCA. In fact, the projection of $\mathrm{Bf}, \mathrm{Ld}$ and $\mathrm{Ss}$ muscles in a plane defined by the first two PC did not show a clear separation of muscles (Figure 1), which points out that, based on the fiber and fat compositions, they did not clearly present different patterns. Comparatively, a study from Costa et al. (2006a) on Ld, Bf and Ss muscles from Maronesa calves of similar age, weight at slaughter and handling, showed higher oxidative metabolism, lower percentages of type IIB and higher proportion of type IIA fibers than Barrosã breed.

Results obtained in pigs suggested that muscle oxidative capacity is primarily related to the presence of type I and IIA muscle fibers but some IIB fibers also exhibit that characteristic (Ruusunen and Puolanne, 1997). The oxidative fibers were positively correlated with IIA fibers in Bf muscle $(P<0.05)$ and with IIB fibers in Ss muscle $(P<0.05)$ in Barrosã calves. Interestingly, type I fibers were negatively correlated with oxidative fibers $(P>0.05)$ in Ld and Ss muscles, suggesting that fibers classified according to mATPase activity could have distinct oxidative enzyme activities among muscles. Muscle fibers location and function are undoubtedly the most important factors that influence fiber type composition within an animal (Lefaucheur and Gerrard, 2000). Contractile and metabolic properties of the same fiber type can vary with anatomical location (Nakatani et al., 2003; Rosser et al., 1992) and within muscle (Armstrong and Laughlin, 1985). Usually, smaller-sized fibers have higher oxidative enzyme activities than larger-sized fibers, even within the same fiber type (Nakatani et al., 2003). The Ss muscle from Barrosã calves had IIB with lower $(P<0.01)$ CSA than $\mathrm{Bf}$ and $\mathrm{Ld}$ muscles. In contrast, the lower $(P<0.05) \mathrm{CSA}$ of type I fibers was found in Bf muscle, suggesting that type IIB and I fibers could be more oxidative in Ss and Bf muscles (respectively) than in their counterparts.

It is generally accepted that high proportion of oxidative fibers implies a greater amount of ITL and NL, due to their ability to use FA as an energy source. For this reason they usually contain higher levels of intra-fiber lipids than the glycolytic counterparts (Alasnier et al. 1996). In apparent contradiction, the proportion of oxidative fibers was negatively correlated with NL content in Bf $(P<0.05), \mathrm{Ld}(P<0.01)$ and Ss $(P>0.05)$ muscles in the current study. Moreover, the latter was more oxidative $(P<0.01)$ and had lower $(P<0.01)$ ITL and NL contents than $\mathrm{Ld}$ muscle. Other studies obtained similar results, and concluded that total lipid content has no relationship with the predominant metabolism of the muscle (Andrés et al., 2001; Leseigneur-Meynier and Gandemer, 1991). The lack of positive correlation between the proportion of oxidative fibers and ITL and NL contents found here could be due to the fact that muscle lipid extract contain not only intramyocellular but also extramyocellular triglycerides (Guo, 2001) and the latter, richer in NL, are more important quantitatively and unrelated to fiber type composition (Essen-Gustavsson et al., 1994). On the contrary, PL content was positively correlated with oxidative fibers $(P<0.05)$ in $\mathrm{Bf}, \mathrm{Ld}$ and Ss muscles which could be associated with a higher relative total membrane surface per volume unit, due to the increased number of mitochondria in oxidative fibers.

The PCA showed weak associations between metabolic/ contractile traits and nutrient composition, suggesting that some other factors could have more biological relevance on lipid composition in Bf, Ld and Ss muscles than fiber composition. As told before, the myosin ATPase histochemical reaction does not necessarily reflect the metabolic capacity of the fibers. Previous studies showed a spectrum of metabolic capacities within a given fiber type, suggesting a specialization within fiber types of a given muscle (Reichmann and Pette, 1982; Rosser et al., 1992). This lack of relationship between mATPase activity and metabolism and the possible different biochemical characteristics within a given fiber type could have contributed to the results obtained.

\subsection{Barrosã-PDO meat composition and dietary recommendations for humans}

On the basis of a daily consumption of a $150 \mathrm{~g}$ steak, trimmed of all visible fat, except for intramuscular fat, Barrosã-PDO meat provides $75-81 \mathrm{mg}$ of cholesterol which represent $25-$ $27 \%$ of the maximum daily cholesterol recommendations ( $<300 \mathrm{mg}$ /day) (USDA, 2005) and $22-28 \%$ and $13-16 \%$ of daily iron recommended requirements for male and female human adults, respectively (Martin et al., 2001).

Optimal dietary intake of CLA remains to be established. However, these are the only natural FA accepted by the National Academy of Sciences of USA as exhibiting consistent antitumor properties at levels as low as $0.25-1.0 \%$ of fat (Eynard and Lopez, 2003). The CLA content in Barrosã meat was more than $0.60 \%$ of fat, with a $150 \mathrm{~g}$ steak providing $16-33 \mathrm{mg}$ of C18:2c9t11-CLA.

Based on $11.3 \mathrm{MJ} /$ day for human adults (25-49 years old), the daily recommended intakes include a minimum of $9000 \mathrm{mg}$ of $n-6$ PUFA and $1500 \mathrm{mg}$ of $n-3$ PUFA (Scientific Review Committee, 1990). Within $n$-3 PUFA, current recommendations for intake of EPA (C20:5 n-3) + DHA (C22:6n-3) range from 270 to $700 \mathrm{mg}$ /day (Givens and Gibbs, 2008). BarrosãPDO meat (150 g) provides $367-558 \mathrm{mg}$ of $n-6$ PUFA and 151$172 \mathrm{mg}$ of $n$-3 PUFA of which $67-78 \mathrm{mg}$ are EPA + DHA.

The $\mathrm{P} / \mathrm{S}$ ranged from 0.26 to 0.37 and was below the nutrition recommendations (British Department of Health, 1994). However, the use of $\mathrm{P} / \mathrm{S}$ ratio for nutritional characterization of ruminant fats may be questioned based on the fact that $\mathrm{C} 18: 0$ might not be a health deleterious FA and ruminant fats have high C18:0 content. An alternative approach might be grouping the FA using a functional (i.e. $\mathrm{h} / \mathrm{H}$ ) rather than the structural criteria $(\mathrm{P} / \mathrm{S})$, as proposed by Santos-Silva et al. (2002). Within the PUFA, the $n-6 / n-3$ ratio in the current research was in agreement with previous studies (Dias et al., 2008; Alfaia et al., 2007) (around 3), which was a slightly higher than dietary guidelines $(<2)$ (Simopoulos, 1999). However, the usefulness of the $n-6 / n-3$ ratio to estimate cardiovascular disease risk of diet fats should be taken with caution (Stanley et al., 2007). 


\section{Conclusions}

This research suggests that fiber type and nutrition compositions vary across Biceps femoris, Longissimus dorsi and Supraspinatus muscles but these parameters were not closely related. Based on $150 \mathrm{~g}$ consumption, the low fat Barrosã-PDO veal provides $367-558 \mathrm{mg}$ of $n-6$ PUFA and $151-172 \mathrm{mg}$ of $n$ 3 PUFA of which $67-78 \mathrm{mg}$ are EPA + DHA. The $n-6 / n-3$ ratio was close to the recommended values for human diet and the $\mathrm{P} / \mathrm{S}$ index was below those values.

\section{Acknowledgments}

This research was supported by the Fundação para a Ciência e Tecnologia (FCT). The authors are grateful to Cooperativa de Boticas and to the Hospital de Santa Maria.

\section{References}

Alasnier et al., 1996 C. Alasnier, H. Rémignon and G. Gandemer, Lipid characteristics associated with oxidative and glycolytic fibres in rabbit muscles, Meat Sci. 43 (1996), pp. 213-224.

Alfaia et al., $2007 \longrightarrow$ C. Alfaia, M. L. F. Castro, M. Quaresma, S. Martins, A. V. Portugal, S. Alves, C. Fontes, R. Bessa, and J. Prates, Effect of slaughter season on fatty acid composition, conjugated linoleic acid isomers and nutritional value of intramuscular fat in Barrosã-PDO veal, Meat Sci. 75 (2007), pp. 44-52.

Andrés et al., 200I A. Andrés, R. Cava, A. Mayoral, J. Tejeda, and J. Ruiz, Oxidative stability and fatty acid composition of pig muscles as affected by rearing system, crossbreeding and metabolic type of muscle fibre, Meat Sci. 59 (200I), pp. 39-47.

Armstrong and Laughlin, 1985 R. B. Armstrong and M. H. Laughlin, Metabolic indicators of fibre recruitment in mammalian muscles during locomotion, J. Exp. Biol. I 5 (1985), pp. 20I-2I3.

British Department of Health, $1994 \rightarrow$ British Department of Health, Nutritional aspects of cardiovascular disease, Report on health and social subjects $n^{\circ} 46$, HSMO, London (1994).

Brooke and Kaiser, $1970 \rightarrow$ M. H. Brooke and K. K. Kaiser, Muscle fiber types: how many and what kind?, Arch. Neur. 23 (1970), pp. 369-379.

Costa et al., 2006a > P. Costa, L. C. Roseiro,V.Alves, A. Partidário, and C. Santos, Histological profile and fatty acid composition of Maronesa-PDO veal muscles, Revista Portuguesa de Ciências Veterinárias I0I (2006), pp. 557-558.

Costa et al., 2006b P. Costa, L. C. Roseiro, A. Partidário, V. Alves, R. J. B. Bessa, C. Calkins, and C. Santos, Influence of slaughter season and sex on fatty acid composition, cholesterol and a-tocopherol contents on different muscles of Barrosã - PDO veal, Meat Sci. 72 (2006), pp. I30-139.

Dias et al., 2008 L. G. Dias, D. M. Correia, J. Sá-Morais, F. Sousa, J. M. Pires, and A. M. Peres, Raw bovine meat fatty acids profile as an origin discriminator, Food Chem. 109 (2008), pp. 840-847.

Essen-Gustavsson et al., $1994 \rightarrow$ B. Essen-Gustavsson, A. Karlsson, K. Lundström, and A. C. Enfält, Intramuscular fat and muscle fibre lipid contents in halothane-gene-free pigs fed high or low protein diets and its relation to meat quality, Meat Sci. 38 (1994), pp. 269-277.

Eynard and Lopez, 2003 A. R. Eynard and C. B. Lopez, Conjugated linoleic acid (CLA) versus saturated fats/cholesterol: their proportion in fatty and lean meats may affect the risk of developing colon cancer, Lipids Health Dis. 2 (2003), pp. I-6.

Folch et al., $1957-$ J. Folch, M. Lees, and G. H. S. Stanley, A simple method for the isolation and purification of total lipids from animal tissues, J. Biol. Chem. 226 (1957), pp. 427-509.

Galbraith et al., 2006 J. K. Galbraith, G. Hauer, L. Helbig, Z. Wang, M. Marchello, and L.A. Goonewardene, Nutrient profiles in retail cuts of bison meat, Meat Sci. 74 (2006), pp. 648-654.

Guo, 2001 Z. Guo, Triglyceride content in skeletal muscle: variability and the source, Anal. Biochem. 296 (200I), pp. I-8.

Givens and Gibbs, 2008 D. I. Givens and R.A. Gibbs, Symposium on 'How can the n-3 content of the diet be improved?' - current intakes of EPA and DHA in European populations and the potential of animal-derived foods to increase them, Proc. Nutr. Soc. 67 (2008), pp. 273-280.
Hornsey, 1956 H. C. Hornsey, The color of cooked cured pork. I. Estimation of the nitric oxidative-haem pigments, J. Sci. Food. Agric. 7 (1956), pp. 534-540.

Instituto do Desenvolvimento Rural e Hidráulica, 2003 Instituto do Desenvolvimento Rural e Hidráulica, 2003. Produtos Tradicionais com Nomes Protegidos - Apuramentos de 2003. Ministério da Agricultura, Desenvolvimento Rural e Pescas (53 Pp.).

ISO 5509, 2000 - ISO 5509, Animal and vegetable fats and oils. Preparation of methyl esthers of fatty acids (2000).

Lefaucheur and Gerrard, 2000 L. Lefaucheur and D. Gerrard, Muscle fiber plasticity in farm animals, J.Anim. Sci. 77 (2000), pp. I-I9.

Leseigneur-Meynier and Gandemer, 1991 A. Leseigneur-Meynier and G. Gandemer, Lipid composition of pork muscle in relation to the metabolic type of the fibres, Meat Sci. 29 (199I), pp. 229-24I.

Lombardi-Boccia et al., 2002 G. Lombardi-Boccia, B. Martinez-Dominguez, and A. Aguzzi, Total heme and non-heme iron in raw and cooked meats, J. Food. Sci. 67 (2002), pp. 1738-1741.

Martin et al., 200 I A. Martin, V. Azais-Braesco, J. L. Bresson, C. Couet, L. Cynober, L. Gueguen, D. Lairon, M. Laville, P. Legrand, P. Pature au Mirand, G. Peres, G. Potier de Courcy, and M.Vidailhet, Apports nutritionnels conseillés pour la population française (3rd ed.) (200I).

Mulvihill, 200I B. Mulvihill, Ruminant meat as a source of conjugated linoleic acid (CLA) - review, Nutr. Bulletin 26 (200I), pp. 295-299.

Nakatani et al., 2003 T. Nakatani,T. Nakashima,T. Kita, and A. Ishihara, Cell size and oxidative enzyme activity of type-identified fibers in rat hindlimb muscles: a review, Acta Histochem. Cytom. 36 (2003), pp. I05-II4.

Ponnampalam et al., 200I E. N. Ponnampalam, A. J. R. Sinclair, S. J. Blakeley, and B. J. Leury, Effects of diets containing $n-3$ fatty acids on muscle longchain $n-3$ fatty acid content in lambs fed low - and medium - quality roughage diets, J.Anim. Sci. 79 (200I), pp. 698-706.

Reichmann and Pette, $1982 \longrightarrow \mathrm{H}$. Reichmann and D. Pette, A comparative microphotometric study of succinate dehydrogenase activity levels in type I, Ila and Illb fibres of mammalian and human muscles, Histochemistry $\mathbf{7 4}$ (I982), pp. 27-4I.

Rosser et al., 1992 B.W. C. Rosser, B. J. Norris, and P. M. J. Nemeth, Metabolic capacity of individual muscle fibers from different anatomic locations, J. Histochem. Cytochem. 40 (1992), pp. 819-825.

Ruusunen and Puolanne, 1997 M. Ruusunen and E. Puolanne, Comparison of histochemical properties of different pig breeds, Meat Sci. 45 (1997), Pp. II $19-125$.

Santos-Silva et al., 2002 J. Santos-Silva, R. J. B. Bessa, and F. Santos-Silva, Effect of genotype, system and slaughter weight on the quality of light lambs: II. Fatty acid composition of meat, Livest. Prod. Sci. 77 (2002), pp. 187-194.

Scientific Review Committee, 1990 Scientific Review Committee, Health and welfare Canada. Nutrition recommendations: The report of the scientific review committee, Minister of supply and services, Ottawa, Canada (1990).

Sharaf et al., 1986 M. A. Sharaf, D. L. Illman, and B. R. Kowalski, Chemometrics, John Wiley, NY, USA (1986).

Sheehan and Hrapchak, 1987 D. C. Sheehan and B. B. Hrapchak, Theory and practice of histotechnology, Battelle Memorial Institute (1987).

Simopoulos, 1999 A. P. Simopoulos, Essential fatty acids in health and chronic disease 70, Am. J. Clin. Nutr. (1999), pp. 560S-569S.

Stanley et al., 2007 J. C. Stanley, R. L. Elsom, P. C. Calder, B. A. Griffin, W. S. Harris, S. A. Jebb, J. A. Lovegrove, C. S. Moore, R. A. Riemersma, and T. A. B. Sanders, Workshop report - UK Food Standards Agency Workshop Report: the effects of the dietary n-6:n-3 fatty acid ratio on cardiovascular health, Br. J. Nutr. 98 (2007), pp. 1305-1310.

STATISTICA, 2004 STATISTICA, Statistica users guide, StatSoft Inc, OK, USA (2004).

SAS 9. I. 3, 2004 SAS 9. I. 3, SAS users guide, SAS inst., Inc., Cary, NC, USA (2004).

USDA, HHS, 2005 USDA, HHS, 2005. Dietary guidelines for Americans 2005. Department of health and human services (HHS) and the department of agriculture (USDA); online (03/07/2006) at http://www. Healthierus. Gov/dietaryguidelines

Valsta and Tapanainen, 2005 L. M.Valsta and H. Tapanainen, Meat fats in nutrition 70, Meat Sci. (2005), pp. 525-530.

VectorWorks, 2003 VectorWorks, Vector works users guide, Nemetschek, USA (2003).

Webb and O'Neill, 2008 E. C.Webb and H.A. O'Neill, The animal fat paradox and meat quality, Meat Sci. 80 (2008), pp. 28-36. 